RECONFIGURING ISLAMIC TRADITION 



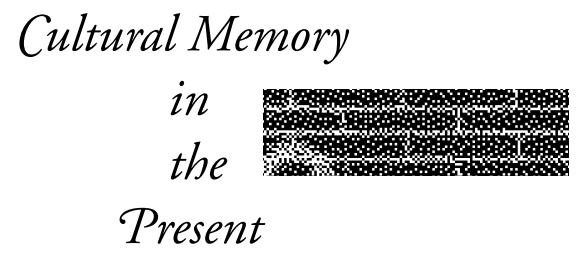

Mieke Bal and Hent de Vries, Editors 



\section{RECONFIGURING ISLAMIC TRADITION}

Reform, Rationality, and Modernity

Samira Haj

STANFORD UNIVERSITY PRESS

STANFORD, CALIFORNIA 
Stanford University Press

Stanford, California

(C) 2009 by the Board of Trustees of the Leland Stanford Junior University.

All rights reserved.

No part of this book may be reproduced or transmitted in any form or by any

means, electronic or mechanical, including photocopying and recording, or in any

information storage or retrieval system without the prior written permission of Stanford University Press.

Printed in the United States of America on acid-free, archival-quality paper

Library of Congress Cataloging-in-Publication Data

Haj, Samira, [date]

Reconfiguring Islamic tradition : reform, rationality, and modernity / Samira Haj.

p. $\mathrm{cm}$.

Includes bibliographical references and index.

ISBN 978-0-8047-5250-3 (cloth : alk. paper)

ISBN 978-0-8047-7860-2 (pbk. : alk. paper)

I. Islamic modernism. 2. Islamic renewal. 3. Islam and reason.

4. Muhammad ibn 'Abd al-Wahhab, 1703 or 4-1792. 5. Muhammad 'Abduh, I849-1905. 6. Philosophy, Islamic-History. I. Title.

BPi66.14.M63 $\mathrm{H}_{33} 2009$

$297.8-\mathrm{dc} 22$

2008011825

Typeset by Westchester Book Group in II/13.5 Adobe Garamond

Chapter 2 is a revised version of "Reordering Islamic Orthodoxy," Muslim World, v. 92 (Fall 2002). 
In memory of my mother, herself a bearer of the tradition 
